Zabytkoznawstwo i Konserwatorstwo XLIV, Toruń 2013

Alicja Jagielska-Burduk*, Dariusz Markowski**

* UKW, Bydgoszcz

** Zakładu Konserwacji i Restauracji Sztuki Nowoczesnej WSP UMK

\title{
Wybrane zagadnienia dotyczące sposobów nabywania własności dzieł sztuki i zabytków przez muzea
}

elem artykułu jest zaprezentowanie sposobów nabywania własności dzieł sztuki i zabytków przez muzea. W pierwszej części opracowa nia zostanie przedstawiona relacja pomiędzy pojęciami muzealiów $z$ ustawy z dnia 21 listopada 1996 r. o muzeach ${ }^{1}$ (dalej: u.m.) a zabytkiem z ustawy z dnia 23 lipca 2003 r. o ochronie zabytków i opiece nad zabytkami (dalej: u.z.o.z.). Następnie zostaną określone sposoby nabycia obiektów zarówno te przewidziane w ustawie o muzeach, jak i inne wynikające w przepisów prawa cywilnego oraz administracyjnego. Już na wstępie warto zauważyć, że muzeum jest szczególnym dysponentem muzealiów i nie korzysta ze swobody rozporządzania nimi. Można zaryzykować stwierdzenie, że muzeum pełni rolę depozytariusza zgromadzonych w nim obiektów dla kolejnych pokoleń. Z kolei w zakresie nabywania nowych obiektów na rynku antykwarycznym muzeum dysponuje dwoma mechanizmami w postaci prawa pierwokupu i pierwszeństwa. Dodatkowo zasób polskich zbiorów dzieł sztuki zarówno tych prywatnych, jak i publicznych został bardzo po-

1 Ustawa z dnia 21 listopada 1996 r. o muzeach, Dz.U. z 1997 r. Nr 5, poz. 24 z późn. zm.

2 Ustawa z dnia 23 lipca 2003 r. o ochronie zabytków i opiece nad zabytkami, Dz.U. Nr 162, poz. 1568 z późn. zm. 
ważnie uszczuplony w okresie II wojny światowej. Natomiast po wojnie ze względu na politykę państwa wyrażającą się $\mathrm{w}$ nacjonalizacji dóbr prywatnych zbiory znajdujące się w posiadłościach dworskich zostały rozproszone, przy czym część z nich znalazła się w muzeach. Ten szczególny przypadek posiadania przez muzea obiektów pochodzących ze zbiorów prywatnych także zostanie poruszony $\mathrm{w}$ artykule. Ostatnia z wymienionych kwestii jest tym bardziej aktualna albowiem w dniu 17 lutego 2012 r. Sąd Najwyższy wydał wyrok III CSK 208/113, w którym uznał za zgodne z prawem posiadanie rzeczy ruchomych przez muzeum przy jednoczesnym potwierdzeniu prawa własności przysługującego właścicielom.

Definicja pojęcia muzealiów została przedstawiona w art. 21 ust. 1 u.m. Zgodnie z treścia powołanego przepisu muzealiami są rzeczy ruchome i nieruchomości stanowiące własność muzeum i wpisane do inwentarza muzealiów. Zdanie drugie przepisu stanowi, że muzealia stanowia dobro narodowe. Już w tym miejscu warto zaznaczyć, iż pierwotna wersja przepisu brzmiała: muzealia wchodzace w skład muzeum muszą być zinwentaryzowane. Wynikało to z faktu, iż w momencie wejścia w życie ustawy o muzeach obowiązywała ustawa o ochronie dóbr kultury (dalej: u.o.d.k. $)^{4}$. W przepisie art. 4 pkt 2 u.o.d.k. przewidziano, iż zabytkami sa dobra kultury wchodzące w skład muzeów, a od momentu wejścia w życie u.m., czyli 1997 r., wpisane do inwentarza muzeów. Zgodnie z treścią przepisu art. 3 u.o.d.k. dobrem kultury w rozumieniu ustawy był każdy przedmiot ruchomy lub nieruchomy, dawny lub współczesny, mający znaczenie dla dziedzictwa i rozwoju kulturalnego ze względu na jego wartość historyczna, naukową lub artystyczną. Stąd też należy przyjąć, że na gruncie u.o.d.k. obiekty określone w ustawie jako dobra kultury po wpisaniu do inwentarza muzeów miały status zabytków.

Nieco inna relacja występuje na tle przepisów u.z.o.z. oraz u.m. Muzealia mają status zabytków, jeżeli spełniają kryteria przepisu art. 3 pkt 1 u.z.o.z. Zgodnie z treścią przepisu art. 3 pkt 1 u.z.o.z. za zabytek uznajemy nieru-

3 Wyrok Sądu Najwyższego z dnia 16 lutego 2012 r. sygn. III CSK 208/11, LEX nr 1162688.

4 Ustawa z dnia 15 lutego 1962 r. o ochronie dóbr kultury, tekst jedn.: Dz.U. z 1999 r. $\mathrm{Nr}$ 98, poz. 1150 z późn. zm. (pierwotnie ustawa o ochronie dóbr kultury i muzeach, Dz.U. z 1962 r. Nr 10, poz. 48). 
chomość lub rzecz ruchomą, ich części lub zespoły, będące dziełem człowieka lub związane z jego działalnością i stanowiące świadectwo minionej epoki bądź zdarzenia, których zachowanie leży w interesie społecznym ${ }^{5}$ ze względu na posiadaną wartość historyczna, artystyczną lub naukowąa. Komentatorzy uznaja, iż obiekt powinien posiadać przynajmniej jedną z wyszczególnionych $\mathrm{w}$ definicji legalnej wartości $\mathrm{w}$ takim stopniu, by zachowanie obiektu $\mathrm{w}$ dobrym stanie leżało $\mathrm{w}$ interesie społecznym ${ }^{7}$. Fragment definicji legalnej zabytku dotyczący wartości, które sprawiają, że obiekt zasługuje na zachowanie dla kolejnych pokoleń można rozpisać wedle sformułowanej przez Maurycego Zajęckiego architektoniki wyidealizowanej definicji zabytku jako pęk własności zabytku tj. „,bycie wartym zachowania, gdyż leży to $\mathrm{w}$ interesie społecznym $\mathrm{z}$ uwagi na posiadaną wartość $\mathrm{E}_{1}$ : historyczną lub $\mathrm{E}_{2}$ : artystyczną lub $\mathrm{E}_{3}$ : naukową"8. Ustawodawca wyróżnia zabytki nieruchome oraz ruchome. Wykładnia przepisu art. 1 u.m. w zw. z przepisem art. 21 ust. 1 u.m. zawierającego definicję legalną muzealiów pozwala przyjać, iż status muzealiów moga mieć nie tylko zabytki'. Z przepisu art. 1 u.m wynika, iż celem muzeum jest gromadzenie i trwała ochrona dóbr naturalnego i kulturalnego dziedzictwa ludzkości o charakterze materialnym i niematerialnym. Wydaje się, że dodatkową wskazówką interpretacyjna przepisu 21 ust. 1 u.m. jest przepis art. 11 u.z.o.z. stanowiący, iż do rejestru nie wpisuje się zabytku wpisanego do inwentarza muzeum. Stąd też można wywodzić, że do inwentarza zabytków mogą być poza zabytkami wpisywane także inne obiekty ruchome i nieruchomości. W pełni podzielamy stanowisko wyrażone przez Maurycego Zajęckiego, iż niepewna jest argumentacja, iż występuje tutaj relacja lex specialis - lex generalis ${ }^{10}$. Nie oznacza to jednak, iż nie można w oparciu o definicję zabytku wska-

5 Szer. A. Jagielska-Burduk, Zabytek ruchomy, Warszawa 2011, s. 56 i n.

6 Por. K. Zeidler, Wartości zabytku jako kategoria normatywna, [w:] Wokót problematyki prawnej zabytkóm i dziet sźtuki, t. 2, red. W. Szafrański, Poznań 2008, s. 37 i n.

A. Soldani, D. Jankowski, Zabytki. Ochrona i opieka. Praktyczny komentarz do nowej ustawy. Tekst ustawy z. dnia 23 lipca 2003 r., Zielona Góra 2004, s. 15.

8 M. Zajęcki w: Kultura w praktyce. Zagadnienia prawne, red. A. Jagielska-Burduk, W. Szafrański, Poznań 2012, s. 33.

9 K. Zalasińska, Pojęcie muzealiów w prawie ochrony dquedzictwa w Prawo muzeów w Polsce, red. J. Włodarski, K. Zeidler, Warszawa 2008, s. 24 i n.

10 Tak trafnie M. Zajęcki w: Kultura w praktyce. Zagadnienia prawne, red. A. Jagielska-Burduk, W. Szafrański, s. 31. 
zać wśród zbioru muzealiów tych, które są desygnatami obu nazw. W konsekwencji zakresy znaczeniowe pojęć krzyżuja się, a nie pokrywaja. Przedstawiona relacja pomiędzy zakresami znaczeniowymi pojęć ma doniosłą rolę w praktyce. W przeprowadzanych badaniach inwentaryzatorskich niejednokrotnie okazuje się, iż w inwentarzu muzeum wpisane są obiekty, które nie maja przymiotu zabytku.

Przyjęta w definicji legalnej muzealiów konstrukcja wymaga spełnienia trzech istotnych przesłanek. Pierwsza z nich dotyczy posiadania statusu rzeczy zarówno rzeczy ruchomej albo nieruchomości. Druga polega na wpisaniu obiektu do inwentarza. Spełnienie trzeciej przesłanki uzależnione jest od dysponowania tytułem prawnym w postaci prawa własności do obiektu $^{11}$. O ile zaistnienie dwóch pierwszych przesłanek jest w praktyce stosunkowo łatwe do stwierdzenia, to ostatnia z nich może niejednokrotnie wymagać przeprowadzenia analizy prawnej statusu własnościowego obiektu. Należy w pełni podzielić stanowisko wyrażone przez Patrycję Antoniak, że „wpis do inwentarza muzealiów jest zatem czynnością faktyczną (materialno-techniczna) konstytuująca domniemanie (domniemanie wynikające z dokumentu urzędowego), że objęte tym wpisem rzeczy ruchome lub nieruchomości stanowią własność muzeum (a w przypadku muzeum prywatnego - założyciela tego muzeum)"'12. W wyroku Sądu Najwyższego z dnia 6 lipca 2007 r. orzekając o wydaniu obrazów rodzinnych powoda zabranych z posiadłości w 1939 r. stwierdzono, że zapisy w księgach inwentarzowych Muzeum Zbrojowni na Zamku w L. nie stanowia przeszkody do uwzględnienia powództwa o wydanie, gdyż jedynie potwierdzają okoliczności, w jakich muzeum weszło w posiadanie tych obrazów, natomiast nie stwarzają tytułu ich własności ${ }^{13}$. Idąc dalej, niesłuszne, chociaż często spotykane $\mathrm{w}$ rozmowach prywatnych stanowisko dotyczące nabycia własności obiektów przez muzeum poprzez wpisanie do inwentarza rozmija się obowiązującymi przepisami prawa.

${ }^{11}$ K. Zalasińska w: Leksylkon prawa ochrony zabytkón. 100 podstawonych pojéc, red. K. Zeidler, Warszawa 2010, s. 165.

12 P. Antoniak, Ustawa o muzeach. Komentary, Warszawa 2012, s. 133-134.

13 Wyrok Sądu Najwyższego z dnia 6 lipca 2007 r., III CSK 86/07, OSNC-ZD 2008, nr 3, poz. 64. 
Organizację inwentarza muzealiów określa rozporządzenie Ministra Kultury z dnia 30 sierpnia 2004 r. w sprawie zakresu, form i sposobu ewidencjonowania zabytków w muzeach. W rozporządzeniu wyróżniono cztery sposoby ewidencjonowania obiektów znajdujących się w muzeum: kartę ewidencyjna, inwentarz muzealiów, prowadzony w formie księgi inwentarzowej, księgę depozytów oraz dokumentację badań archeologicznych i innych badań terenowych. Istotnym z punktu widzenia kontroli zasadności ujmowania pewnych obiektów w inwentarzu muzealiów jest także \3 ust. 6 powołanego rozporządzenia. Nakłada on bowiem obowiązek przeprowadzania systematycznych komisyjnych kontroli zgodności wpisów dokumentacji ewidencyjnej ze stanem faktycznym zbiorów. Kontrola powinna być przeprowadzana się co pięć lat od daty zakończenia poprzedniej kontroli. Organizator muzeum ${ }^{14}$ może przedłużyć ten okres do 10 lat. Kontrole działalności muzeów prowadzone przez Najwyższą Izbę Kontroli ujawniają że obowiązek ten nie zawsze jest realizowany. Wedle struktury organizacyjnej muzeum podmiotem odpowiedzialnym za dopełnienie obowiązku polegającego na prowadzeniu ewidencji obiektów odzwierciedlającej ich status prawny jest dyrektor muzeum ${ }^{15}$.

Pomimo iż muzeum może posiadać muzealia stanowiące rzeczy ruchome i nieruchome, to podjęta w pracy analiza będzie w przeważającej części dotyczyć muzealiów - zabytków ruchomych. Właśnie w stosunku do obiektów ruchomych, które na skutek rozlicznych i mających różne źródło zdarzeń historycznych znalazły się w muzeach wydawano decyzję o wpisie do inwentarza zabytków. Dlatego w tym zakresie dążenie do transparentności prawnej jest szczególnie istotne. Zwłaszcza w sytuacji, gdy minęło już ponad 20 lat od zmiany ustroju, a standardy funkcjonowania podmiotów publicznych w państwie prawa są wysokie.

14 Zgodnie $\mathrm{z}$ treścią przepisu art. 5 ust. 1 um organizatorem muzeum może być: minister i kierownik urzędu centralnego, jednostka samorządu terytorialnego, osoba fizyczna, osoba prawna lub jednostka organizacyjna nie posiadająca osobowości prawnej.

15 Najwyższa Izba Kontroli, Departament Nauki, Oświaty i Dziedzictwa Narodowego, Nr ewid: 11 /2009/P/08/75/KNO, KNO - 41001/08, Informacja o wynikach kontroli ochrony i udostępniania zasobów muzealnych w Polsce, Warszawa 2009, plik dostępny: http://www.nik.gov.pl/aktualnosci/nik-o-muzeach.html (dostęp z dnia 26 sierpnia 2012 r.). 
Wśród sposobów nabycia własności obiektów, które po wpisaniu do inwentarza będa miały status muzealiów, można wyróżnić nabycie wynikające z umowy oraz inne sposoby nabycia. Spośród umów zawieranych przez muzea należy wymienić umowę sprzedaży oraz umowę darowizny ${ }^{16}$. Chcąc wskazać inne sposoby nabycia własności obiektów przez muzea, należałoby rozważyć nabycie w drodze dziedziczenia czy też na podstawie zapisu testamentowego, zasiedzenie nieruchomości czy rzeczy ruchomej, nabycie od nieuprawnionego, nabycie na podstawie aktu prawa na przykład dekretu o przeprowadzeniu reformy rolnej, nabycie w toku egzekucji sądowej oraz na podstawie orzeczenia sądu.

Nabywanie obiektów przez muzea w drodze umowy sprzedaży zostało uregulowane w u.m. Niejednokrotnie plany zakupowe sa uzgadniane $\mathrm{z}$ rada muzealna $a^{17}$. Zgodnie z przepisem art. 6 ust. 2 pkt 4 u.m. w statucie muzeum określa się organy doradcze i sposób ich powoływania. W przepisie art. 11 u.m. wskazano zakres działania rady muzeum, zgodnie z którym rada muzeum sprawuje nadzór nad wypełnianiem przez muzeum jego powinności wobec zbiorów i społeczeństwa, w szczególności nad realizacją celów określonych w art. 1 u.m. oraz ocenia, na podstawie przedłożonego przez dyrektora muzeum sprawozdania rocznego z działalności, działalność muzeum oraz opiniuje przedłożony przez dyrektora roczny plan działalności. Przykładowo konsultacji z radą muzeum wymaga sytuacja, gdy planowany zakup dotyczy obiektu bardzo wartościowego i będzie mieć duży wpływ na gospodarkę finansową muzeum, np. zakup obiektu Brama Floriańska przez Muzeum Okręgowe w Bydgoszczy im. Leona Wyczółkowskiego z okazji roku Wyczółkowskiego i 80 rocznicy urodzin patrona muzeum. Opinia rady muzealnej jako ciała kolegialnego jest wyrażana w formie uchwały. W przypadku muzeów zarejestrowanych minister może powierzyć swoje uprawnienia radzie powierniczej, która w zakresie nabywania zbiorów pełni tożsamą funkcję $\mathrm{z}$ radą muzeum.

Obligatoryjnie opinia rady muzealnej wymagana jest w przypadku deakcesji zbiorów w postaci umów zamiany, sprzedaży lub darowizny muze-

16 Szerzej: A. Jagielska. W. Szafrański, Darowizny na rzecz. muzeów, [w:] Wokót problematyki prawnej zabytkón i dziet sztuki, t. 2, Poznań 2008, s. 69-80.

17 Por. J. A. Chrościcki, Rady muzealne. Uwagi na temat podstaw prawnych, funkcjonowania $i$ żnaczenia prawnego, red. J. Włodarski, K. Zeidler, Warszawa 2008, s. 31 i n. 
aliów. Pozwolenie w formie decyzji administracyjnej wydawane jest przez ministra do spraw kultury i ochrony dziedzictwa narodowego, po zasięgnięciu opinii Rady do Spraw Muzeów na skutek wniosku dyrektora muzeum zaopiniowanego przez radę muzeum. Ustawa z dnia 31 sierpnia $2011 \mathrm{r}$. o zmianie ustawy o organizowaniu i prowadzeniu działalności kulturalnej ${ }^{18}$ oraz niektórych innych ustaw wyeliminowała z trybu organizatora, za którego pośrednictwem muzeum składało wniosek. W uzasadnieniu aktu wskazywano, że organizator nie zajmował merytorycznego stanowiska w sprawie, stąd też jego uczestnictwo w trybie uzyskania pozwolenia na deakcesję zbiorów było nieuzasadnione ${ }^{19}$. Zmieniono także okoliczności, w których wydawane jest pozwolenie z budzących wattpliwości interpretacyjne „w wyjattkowych i uzasadnionych” na „uzasadnione”.

Wielopoziomowa kontrola to nic innego jak funkcjonujące we współczesnych przedsiębiorstwach wewnętrzne mechanizmy kontroli oraz co najważniejsze gwarancja eliminacji wadliwych decyzji w zakresie rozporządzania muzealiami. Warto zwrócić uwagę, że środki pozyskane w ten sposób moga być przeznaczone wyłącznie na uzupełnienie zbiorów muzeum, bez względu na aktualna gospodarkę finansową muzeum i jego sytuację finansowa. Ustawodawca nie przewidział jednak terminu, w którym przeznaczenie danej kwoty na nowy zakup powinno być wykorzystane, stąd też istnieje możliwość stworzenia wyodrębnionej rezerwy na ten cel. Sztywne wskazanie okresu wydatkowania sprawiłoby problem przy rozliczeniach rocznych aktywów muzeów oraz determinowałoby szybkie, co nie zawsze oznacza dobre podejmowanie decyzji w zakresie nabywania nowych obiektów.

Warto zwrócić uwagę na fakt, że muzeum rejestrowane, jako podmiot na rynku sztuki, ma pozycję uprzywilejowana. W ramach uprzywilejowania muzeum ma prawo skorzystać z określonych w przepisie art. 20 u.m. ustawowo przyznanych możliwości w postaci prawa pierwokupu zabytku sprzedawanego na aukcji oraz prawa pierwszeństwa zakupu od podmio-

18 Dz.U. Nr 207, poz. 1230.

19 Rządowy projekt ustawy o zmianie ustawy o organizowaniu i prowadzeniu działalności kulturalnej oraz niektórych innych ustaw. Uzasadnienie do projektu, druk 3786, s. 32. Wypada zaznaczyć, że po likwidacji instytucji kultury majątek jej przechodzi na organizatora. W tym też należy upatrywać uzasadnienia poprzedniego brzmienia przepisu. 
tów prowadzących działalność polegająca na oferowaniu do sprzedaży zabytków. Wypada zaznaczyć, że przepisy tworzące pozycję muzeum na rynku sztuki były nieprecyzyjne i stwarzały wiele wattpliwości interpretacyjnych ${ }^{20}$. Praktycznie od początku obowiązywania u.m. regulacja prawa pierwszeństwa i prawa pierwokupu pozostawała poza kosmetyczną zmiana na skutek wejścia w życie u.z.o.z. niezmienna, by dopiero po wejściu w życie ustawy z dnia 31 sierpnia 2011 r. o zmianie ustawy o organizowaniu i prowadzeniu działalności kulturalnej oraz niektórych innych ustaw przybrać doprecyzowany kształt. Nowelizacja ustawą z dnia 31 sierpnia 2011 r. o zmianie ustawy o organizowaniu i prowadzeniu działalności kulturalnej oraz niektórych innych ustaw ${ }^{21}$ nadała przepisom nowe brzmienie. Rozwiązano także kwestię złożenia oświadczeń o skorzystaniu z prawa pierwokupu przez dwa muzea, w myśl zasady prior tempore, potior iure. Istotnym rozwiązaniem, którego brak wskazywano pośrednio we wcześniejszych omówieniach przepi$\mathrm{su}^{22}$, jest wyraźne stwierdzenie w przepisie art. 20 ust. 4 u.m., że sprzedaż dokonana $\mathrm{z}$ naruszeniem prawa pierwszeństwa, o którym mowa w przepisie art. 20 ust. 1, oraz prawa pierwokupu, o którym mowa w przepisie art. 20 ust. 2 , jest nieważna.

Nie bez znaczenia dla pozycji muzeum na rynku sztuki jest rozwiązanie pozwalające zgłosić wolę skorzystania z prawa pierwokupu nie później niż do zakończenia całej aukcji. Przykładowo można wyobrazić sobie trzy sytuacje, w których to dodatkowe uprzywilejowanie może determinować nabycie obiektu czy obiektów na aukcji ${ }^{23}$. Pierwsza, w której pełnomocnik muzeum otrzymał pełnomocnictwo do zawarcia umowy do wartości przedmiotu wynoszącej 100 tysięcy złotych, a interesujący muzeum obiekt uzyskał cenę wylicytowaną 110 tysięcy zł. Pełnomocnik ma zatem do koń-

20 P. Stec, Szczególne uprawnienia muzeón rejestrowanych w zakeresie obrotu dzietami sẓtuki, „Muzealnictwo", 2005, nr 46, s. 182 i n.

21 Ustawa z dnia 31 sierpnia 2011 r. o zmianie ustawy o organizowaniu i prowadzeniu działalności kulturalnej oraz niektórych innych ustaw, Dz.U. 2011, nr 207, poz. 1230.

22 Por. M. Stanulewicz, Szczegóme uprawnienia muzeón do nabywania zabytków w śnietle art. 20 ustawy o muzeach, [w:] Wokót problematyki prawnej zabytkón i dzię štuki, red. W. Szafrański, Poznań 2007, s. 117, 121.

23 Por. inaczej K. Mularski, W sprawie ustawowego prawa pierwokupu praystugujacego mu々eom rejestrowanym, [w:] Kultura w praktyce. Zagadnienia prawne, s. 130 i n. 
ca aukcji czas, aby zdobyć nowe pełnomocnictwo, a w pierwszej kolejności pozwolenie dyrektora instytucji na zgłoszenie prawa pierwokupu w cenie wylicytowanej większej, aniżeli muzeum pierwotnie zamierzało wydać. Podobna sytuacja zaistnieje, gdy muzeum ma przeznaczone 100 tysięcy zł na zakup, a cena wylicytowana jest o 30 tysięcy większa. Wówczas można ewentualnie wykorzystać czas do końca aukcji na poszukiwanie sponsora czy też kontakt $z$ organizatorem muzeum, np. jednostką samorządu terytorialnego czy minister lub organ administracji centralnej. Ciekawe zastosowanie może mieć nowa regulacja w przypadku aukcji, na której licytowane są dzieła przynależące do kolekcji ${ }^{24}$. Wówczas uczestnik aukcji reprezentujący muzeum może przeanalizować, czy kupić obiekty wedle pierwotnej decyzji, czy też zmodyfikować decyzję, wybierając czy wymieniając obiekty na inne celem uzyskania jak najkorzystniejszego zbioru przy jednoczesnej optymalizacji poniesionych na wybrane elementy kosztów.

Kolejnym sposobem nabycia własności jest nabycie poprzez objęcie w posiadanie obiektów porzuconych przez dotychczasowych właścicieli. $\mathrm{O}$ ile $\mathrm{w}$ stosunku do mienia poniemieckiego wydano nawet odrębny akt prawny ${ }^{25}$ regulujący tę kwestię, to w odniesieniu do obiektów przewiezionych celem zabezpieczenia do muzeów po II wojnie światowej nie ma takiego aktu. Obiekty ruchome, tj. obrazy, serwisy czy też rzeźby, którym nie można było przypisać właściciela były przejmowane do muzeów. Część z dzieł ukrytych podczas wojny stopniowo odnajdywano po 1945 r. Dzieła te przewożono do pracowni konserwatorskich w celu ich zabezpieczenia, a następnie rozdzielano do muzeów. Stan niektórych był wręcz dramatycz$n y^{26}$. Podejmowane działania miały na celu zachowanie zasobu dziedzictwa kulturalnego niezależnie od podmiotu właściciela (takie założenie funkcjonuje również w konwencji haskiej). W obowiązującym po 1945 r. systemie prawnym możliwe było nabycie własności obiektów porzuconych poprzez objęcie ich w posiadanie. Nie bez znaczenia jest tutaj kwestia historycznego uwarunkowania porzucenia obiektów oraz realna możliwość domagania się wydania rzeczy przez pozbawionego posiadania właściciela. Zarówno dekret

24 Przyjmujemy, że kolekcja nie jest wpisana do rejestru zabytków.

25 Dekret z dnia 8 marca 1946 r. o majątkach opuszczonych i poniemieckich, Dz.U. $\mathrm{Nr} 13$ poz. 87 ze zm.

26 AAN, 3/146, Ministerstwo Kultury i Sztuki, k. 21, 22. 
o prawie rzeczowym, jak i kodeks cywilny regulują instytucje zawłaszczenia polegającą na nabyciu pierwotnym rzeczy oraz przejęcia własności rzeczy przez znalazcę po upływie określonego czasu. Zgodnie z treścia przepisu art. 181 k.c. własność ruchomej rzeczy niczyjej nabywa się przez jej objęcie w posiadanie samoistne. Dla nabycia własności konieczne jest, aby obiekt został porzucony przez właściciela przy zamiarze wybycia się własności tej rzeczy ${ }^{27}$. Nie podpada pod treść tego przepisu sytuacja, w której właściciel ucieka z domu w okresie wojennym, pozostawia swój majątek pod opieka zarządcy czy też innego pracownika ${ }^{28}$.

Przywołania wymaga także nabycie własności rzeczy ruchomej w trybie przepisu art. 187 k.c. W przepisie art. 187 k.c. przewidziano możliwość nabycia przez Skarb Państwa własności pieniędzy, papierów wartościowych, kosztowności oraz rzeczy mających wartość naukową lub artystyczną, które nie zostana przez uprawnionego odebrane w ciagu roku od dnia wezwania go przez właściwy organ, a w razie niemożności wezwania - w ciagu dwóch lat od ich znalezienia. Warto zaznaczyć, że w wyroku Sądu Najwyższego z dnia 11 lutego 1997 r. ${ }^{29}$ wyrażono stanowisko, iż do 1989 r. miało miejsce zawieszenie działalności organów Państwa i pogląd ten przyjęto także w sprawie ustalenia nabycia własności obiektów mających proweniencje prywatna przez Skarb Państwa w drodze przemilczenia ${ }^{30}$.

Inna sytuacja pojawia się w stosunku do obiektów przejętych na rzecz Skarbu Państwa na podstawie dekretów wydanych w latach 1944-1946, w tym dekretu o przeprowadzeniu reformy rolnej $j^{31}$ W opracowaniach prawnych kilkakrotnie podejmowano się udzielenia odpowiedzi na pytanie, czy przepisy dekretu miały zastosowanie do znajdujących się w dworkach dzieł sztuki ${ }^{32}$. Wyrażono dwa odmienne stanowiska: pierwsze wyłączające

\footnotetext{
27 J. Nadler w: Kodeks cymilny. Komentarz, red. E. Gniewek, Warszawa 2011, s. 331.

28 Wyrok Sądu Najwyższego z dnia 6 lipca 2007 r., III CSK 86/07, OSNC-ZD 2008, nr 3, poz. 64.

29 Wyrok Sądu Najwyższego z dnia 11 lutego 1997 r., II CKN 78/96, LEX nr 5538.

30 Wyrok Sądu Najwyższego z dnia 6 lipca 2007 r., III CSK 86/07, OSNC-ZD 2008, nr 3, poz. 64.

31 Dekret z dnia 6 września 1944 r., Dz.U. 1945, nr 3, poz. 13 ze zm.

32 Szerzej: A. Jagielska, W. Szafrański, Rekompensata cayy zurot? Wokót problematyki zabytków ruchomych przejetych w trakcie realizacii reformy rolnej z. 1944 r., [w:] Wokót problematyki prawnej zabytków i dziet squtuki Poznań 2007 i tam cytowana literatura.
} 
możliwość przejęcia własności ruchomości pochodzących z mienia podworskiego oraz drugie, w którym przyjęto, że na podstawie przepisów dekretu miało miejsce skuteczne nabycie prawa własności33. Bliższe autorom niniejszego artykułu jest zdecydowanie stanowisko pierwsze. Wyraża ono nie tylko świadomość wadliwości podejmowanych przez poprzednie organy państwa decyzji, ale także dbałość o realizację zasady sprawiedliwości społecznej i przejęcia odpowiedzialności przez obecne organy państwa - następców prawnych - za działania organów w przeszłości ${ }^{34}$.

Skarb Państwa oraz jednostka samorządu terytorialnego będąca organizatorem muzeum może także nabyć własność obiektu ruchomego w dobrej wierze. W myśl cywilistycznej koncepcji domniemania dobrej wiary zgodnie treścią przepisu art. 7 k.c., jeżeli ustawa uzależnia skutki prawne od dobrej lub złej wiary, domniemywa się jej istnienia. W konsekwencji podmioty te moga zasiedzieć posiadane przez nie obiekty, jeżeli ustali się, iż w okresie trzech lat były w dobrej wierze. Nie ma znaczenia fakt, iż po nieprzerwanym trzyletnim posiadaniu $\mathrm{w}$ dobrej wierze, posiadacz popadł w zła wiarę, a w tym przypadku dowiedział się o proweniencji obiektu. Wykazanie przez wyzutego z posiadania właściciela istnienia po stronie posiadacza - muzeum - złej wiary powinno odbywać się na dwóch płaszczyznach. Pierwszej polegającej na sprawdzeniu faktycznych wpisów w karcie inwentarzowej obiektu i dat ich sporządzania. Nadto, jeżeli będzie to możliwe na podstawie dokumentów lub innych dostępnych środków dowodowych, należy ustalić okoliczności nabycia posiadania obiektu. Druga płaszczyzna to zagadnienia związane $\mathrm{z}$ realizowaniem przez muzeum ustawowych obowiązków polegających na szeroko rozumianej opiece nad zbiorami. W ramach opieki w muzeum powinny być przeprowadzane inwentaryzacje. Nie sposób pominać, iż kwestia proweniencji dzieł została także poruszona w Kodeksie etyki dla muzeów ICOMOS ${ }^{35}$. W art. 2 Kodeksu etyki

33 Por. K. Zeidler, Restytucja dóbr kultury ze stanowiska filozofii prawa. Trudnych praypadkach na granicy kultury i prawa, Warszawa 2011, s. 207 i tam cytowana literatura.

34 Kwestia własności obiektu pojawi się przy okazji digitalizacji zbiorów znajdujących się w muzeum. Pomijając aspekt prawnoautorski, każdorazowo zgodę na wykorzystanie wizerunku obiektu powinien wyrazić także właściciel obiektu.

35 Kodeks etylki dla muzeón ICOM, tłum. P. Rybiński w: Prawo muzeón, red. J. Włodarski, K. Zeidler, Warszawa 2008, s. 138 i n. 
dla muzeów zawarto wytyczne postępowania w zakresie obiektów nabywanych przez muzea. Obiekty te powinny mieć uznana proweniencję oraz nie mieć wad prawnych. Przenosząc te wymagania na już posiadane zbiory muzealne, można uznać, że także w odniesieniu do nich muzealnicy powinni kierować się pewnymi zasadami związanymi z poszanowaniem praw osób trzecich i ze świadomością skomplikowanego pod względem historycznym i prawnym gromadzenia polskich zbiorów muzealnych. Konkludując, przyznanie przez Sąd Najwyższy w wyroku z dnia 16 lutego 2012 r., sygn. akt III CSK 208/11 prawa posiadania muzeum nie zwalnia muzeum z moralnego obowiązku wydania obiektów właścicielom wynikającego z Kodeksu etyki dla muzeów, a wiec soft law obowiązującego polskie muzea.

Sąd Najwyższy w wyroku z dnia 16 lutego 2012 r. uznał, że

roszczenia powodów okazały się roszczeniami naturalnymi, tj. pozbawionymi cechy moźliwości wymuszenia ich wykonania na drodze sądowej. W rezultacie powodowie - mimo iż nie utracili własności objętych pozwem rzeczy - nie mogli odzyskać ich posiadania. Z tego powodu ich sytuacja prawna stała się ułomna. Niemożność realizacji przy zastosowaniu przymusu państwowego tak istotnego atrybutu własności jak roszczenie windykacyjne, nie podważa jednak samej istoty prawa własności ${ }^{36}$.

Właścicielowi nie przysługuje już zatem roszczenie rewindykacyjne, ale nadal ma on względem muzeum roszczenie w postaci naturalnej. Dlatego też nie ma przeszkód, aby muzeum dobrowolnie zwróciło obiekty właścicielowi. W przypadku przeniesienia posiadania, muzeum nie będzie już mogło żądać wydania rzeczy z powrotem. Szczególnie cenne może okazać się dla przyszłej polityki państwa w zakresie zarządzania dobrami kultury stwierdzenie, że „roszczenie naturalne wskutek przedawnienia może zawsze stać się roszczeniem zupełnym w następstwie zrzeczenia się przez zobowiązanego korzystania z zarzutu przedawnienia" ${ }^{37}$. W ten sposób muzeum, zrzekając się poprzez jednostronne oświadczenie woli złożone przez pod-

36 Wyrok Sądu Najwyższego z dnia 16 lutego 2012 r. sygn. III CSK 208/11, LEX nr 1162688.

37 Wyrok Sądu Najwyższego z dnia 16 lutego 2012 r. sygn. III CSK 208/11, LEX nr 1162688. 
miot uprawniony, mogłoby wydać obiekty ich właścicielom w toku sprawy sądowej. Należałoby nawet rozważyć, czy wobec niechęci prawodawcy do objęcia zabytków i dzieł sztuki ustawą reprywatyzacyjną nie warto stworzyć pewnego stałego modelu postępowania w sprawach roszczeń rewindykacyjnych na poziomie Ministerstwa Kultury i Dziedzictwa Narodowego. Nawet jeżeli pierwotnie myśl, aby skorzystać z legalnego prawa posiadania i powstania po stronie właściciela nudum ius przy zatrzymaniu zbiorów w muzeach, muzea, a w konsekwencji ich organizatorzy narażają się na ocenę działania zgodnego z prawem, ale niezgodnego z moralnością, a na taka ocenę w XXI wieku państwowy sektor kultury nie może sobie pozwolić38.

W ocenie autorów artykułu bardzo ważne jest dążenie do rozwiązania sprawy odnoszaccej się do statusu własnościowego obiektu jeszcze na etapie przedsądowym. W sytuacji asymetrii informacyjnej pozbawiony posiadania właściciel jest jednak w zdecydowanie bardziej niekorzystnej sytuacji w stosunku do muzeum. Nie zawsze może wykazać się kompletem dokumentów oraz innymi dowodami potwierdzającymi proweniencję obrazu oraz niezmieniony status własnościowy potwierdzający jego własność obiektu. Nie jest przecież tajemnica, że pozycję negocjacyjna zdobywa się przede wszystkim posiadanymi dowodami oraz uprzednim przeprowadzeniem profesjonalnej analizy prawnej.

Niekorzystna pozycja muzeów w takim sporze może budzić sprzeciw wielu osób. Pomimo podejmowanych prób udowodnienia nabycia własności obiektów, muzea są wielokrotnie na przegranej pozycji. W rozmowach prywatnych muzealnicy zastanawiają się, jak to możliwe, że odnaleziony na aukcji obraz wstawiony przez osobę trzecią stanowi już jej przedmiot własności, chociaż odziedziczyła obiekt po osobie związanej z kradzieżą tego obiektu z muzeum dokonana ponad pół wieku temu. Odpowiedź choć dla współczesnego przedstawiciela nauki prawa cywilnego jest prosta, to jej uzasadnienie wymaga wyważenie interesów publicznego i prywatnego oraz odniesienia się do historii powojennego muzealnictwa. Skarb Państwa, jednostki samorządu terytorialnego i funkcjonujące na ich terenie instytucje

38 Szerzej: W kontekście zastosowania art. 5 k.c. do sprawy: A. Jagielska-Burduk, K. Mularski, Problematyka reprywatyzacï zabytkón ruchomych. Uwagi na marginesie uyroku Sadu Najuyz;szego z. dnia 16 lutego 2012 r. (III CSK 208/11), w druku. 
kultury mają ograniczone możliwości nabycia obiektów ruchomych. Muzea z kolei powinny przede wszystkim mieć na uwadze nie tylko normy etyczne, które winny być przestrzegane, ale poczucie obowiązku wobec przyszłych pokoleń. Problematyka ta jest na tyle wrażliwa, że niechętnie jest też podejmowana w projektach ustaw reprywatyzacyjnych. Przykładowo ostatni projekt ustawy o świadczeniach pieniężnych przyznawanych niektórym osobom, których dotyczyły procesy nacjonalizacji, nie obejmuje wyposażenia mieszkań, dzieł sztuki, obrazów ${ }^{39}$. Czy nie byłoby przyjemniej podziwiać w muzeach obiekty, których właściciele zawarli umowę użyczenia z muzeum, a nie trwaja w niepewności, czy w końcu ich własność zostanie uznana. Warto na zakończenie podkreślić, że niektórym właścicielom nie zależy na odzyskaniu posiadania, a jedynie na potwierdzeniu ich tytułu własności. Nie można jednak oceniać negatywnie właścicieli, którzy wysuwając roszczenie rewindykacyjne, zamierzaja przeznaczyć pieniądze pozyskane z późniejszej sprzedaży dzieła na potrzeby życiowe czy też inwestycyjne.

Podsumowując, sposoby pozyskania własności obiektów przez muzea można podzielić na wynikające $\mathrm{z}$ umowy w tym umowy sprzedaży, darowizny, wymiany oraz inne sposoby nabycia własności w tym zasiedzenie i objęcie w posiadanie rzeczy porzuconej. Inne sposoby nabycia własności związane sa ze zjawiskiem przejmowania do muzeów obiektów zabezpieczonych podczas działań wojennych i odnalezionych po I lub II wojnie światowej oraz przejętych przez państwo podczas realizacji dekretów nacjonalizacyjnych. Do dzisiaj fakt nabycia własności obiektów wydaje się kontrowersyjny i jest rozpatrywany w oparciu o ustalony w konkretnej sprawie stan faktyczny. Nie zmienia to faktu, iż aprobata przez reprezentantów państwa stanu faktycznego w sprawie dóbr pochodzących z majątku rodziny Sanguszków nie sprzyja pochlebnej ocenie działania państwa, chociażby miało uzasadnienie $\mathrm{w}$ obowiązującym prawie ${ }^{40}$. Warto podkreślić, iż prze-

39 Projekt ustawy o świadczeniach pieniężnych przyznawanych niektórym osobom, których dotyczyły procesy nacjonalizacji z dnia 18 maja 2009 r. Z informacji na stronie internetowej Ministerstwa Skarbu Państwa wynika, iż projekt ze względu na czynione oszczędności, kryzys ekonomiczny projekt ze względu na duże obciążenie finansowe nie może być przeprowadzony.

40 Por. A. Jagielska-Burduk, K. Mularski, Problematyka reprywatyzacï zabytków ruchomych. Uwagi na marginesie myroku Sadu Najuyisszego z dnia 16 lutego 2012 r. (III CSK 208/11), w druku. 
pisy obowiązujących kodeksów były konstruowane z myślą i założeniem prawidłowego funkcjonowania państwa. We wskazanej sytuacji sprawa rozważana była na tle rzeczywistości dalekiej od wyrażającej zasady ochrony własności prywatnej.

\section{Summary}

\section{Legal problems concerning acquiring cultural objects by museums}

The article presents the ways of acquiring cultural objects by museums in the Polish law. Museums have special prerogatives in buying objects from professionals (priority right) as well as the right of pre-emption on auctions stipulated in museums law. All the above constitute museums as privileged participants on the art market. The deaccesion of museums' collections is supervised by The Ministry of Culture and National Heritage. All transactions, sales, exchange or donations included, require the Minister's permit. The supervision system is a result of the regulations on the protection of cultural heritage and the will to keep as many objects as possible in the museums. Sometimes legal status of the objects in question is not transparent (ex. an object is private property that was placed in museum because of nationalization, war etc.). In such cases the museum should consider to return the object to the legal owner or to buy it from them. If the object is in the museum's possession, the limitation regulations can be applied. Then the museum only has a moral duty to fulfill the legal owner's demand (Polish Supreme Court verdict from 17 February 2012, III CSK 208/11). 